\title{
INVESTIGATION ON DIESEL ENGINE FUELLED BY MAHUA BIODIESEL
}

\author{
M.Kannan', R.Balaji ${ }^{2}$, R.T Sarath Babu ${ }^{3}$, Chandrakant B.Shende ${ }^{4}$, Ashish Selokar ${ }^{5}$ \\ ${ }^{I}$ Department of Mechanical Engineering, KCG College of Technology, Chennai, India \\ ${ }^{2}$ Department of Mechanical Engineering, Hindustan Institute of Technology \& Science, Chennai, India \\ ${ }^{3}$ Department of Mechanical Engineering, Mother Theresa Institute of Engineering \& Technology(MTIE), Melumoi Post, \\ Palamaner - 517408, Chittoor (D.T) A.P. \\ ${ }^{4}$ Department of Botany, Mohsinbhai Zaweri Mahavidyalaya, Desaiganj (Wadsa), Dist- Gadchiroli 441207 \\ ${ }^{5}$ Department of Physics, Mohsinbhai Zaweri Mahavidyalaya, Desaiganj (Wadsa), Dist- Gadchiroli 441207
}

\begin{abstract}
The primary objective of this study is to discover the effects of injection timing on performance, emission and combustion characteristics effect of advanced and retarded injection timing of the engine fuelled with mahua oil biodiesel blends. The engine performance, combustion and emission characteristics of the mahua oil biodiesel blends (B20, B40, B60, B80and B100) are investigated in this experimentation without any modification of the diesel engine. At this advanced pressure $t$ he efficiency of engine by means of $\mathrm{CO}$, Unburned HC gases and smoke emissions with higher oxides of nitrogen was observed compared to diesel. The obtained results are compared with a neat diesel and mahua oil biodiesel blends are shown through the graphs. From this study, identifies optimum fuel blend of this work. Thus, the combustion of duration is similar in all variance in pressure. This research paved a way to bio-diesel in mahua oil mixture and draws best outcome in emission less and to maintain eco-friendly environment.
\end{abstract}

Keyword: Mahua Biodiesel, Diesel Engine, Blending, Performance, Combustion, Emission

\section{Introduction}

An Improvement of diesel engine performance efficiency fuelled by mahua biodiesel blends with octanol using the transesterification process has been performed to prepare biodiesel through mahua oil. Based on the analysis, $\mathrm{CO}$ emissions decreased when octanol mixtures increased [1-9]. In all load conditions, total $\mathrm{CO}$ emissions were observed to decrease by $6.8 \%$ and $7.4 \%$ for M80O20 and M90010 compared to pure mahua biodiesel. Also, it shows a decrease in the NOx, HC, and smoke emissions with an increase in octanol proportions. The $20 \%$ octanol blend showed a significant decrease in overall engine emissions [10]. The effect of the high - octane fuel induction combustion behavior of the engine fuelled by mahua biodiesel. The engine was powered by a jet carburetor especially designed for the supply of high octane fuels for dual fuel mode. At full load condition, the experiment results revealed a major development incylinder pressure and the highest pressure increase with dual fuel mode of all tested fuels. Dual fuel mode is a higher ignition delay due to the mixing of both fuels in comparison to single-mode fuels. The duration of combustion lowered in the dual fuel operation at full load condition compared to Neat Mahua Oil (NMO) but increased at a $40 \%$ load [11]. The B20 fuel showed better results than the diesel base, such as lower partial load performance, combustion, and emissions. In this Research, parametric optimization study for the performance and emissions of the direct injection diesel Mahua biodiesel engine. Experiments have measured various combustion, performance, and emission characteristics and have been validated using the Grey Relational Grade (GRG) method an approach to desirability was used to find the optimum combination [12].

\section{Experimental Set-Up}

Figure 1.shows the experimental setup of the engines. The setup consists of a four-stroke, single cylinder, water - cooled, vertically mounted direct injection engine with a constant speed of $1500 \mathrm{rpm}$ and a fixed compression ratio of 16 , with eddy current dynamometer loading. This type of engine is used in India as a primary mover for industrial, agricultural, power generation and construction purposes. The engine setup is provided with the instruments required to measure operating parameters such as fuel flow, air flow, crank angle, temperatures, cylinder pressure, and load [13-15]. 


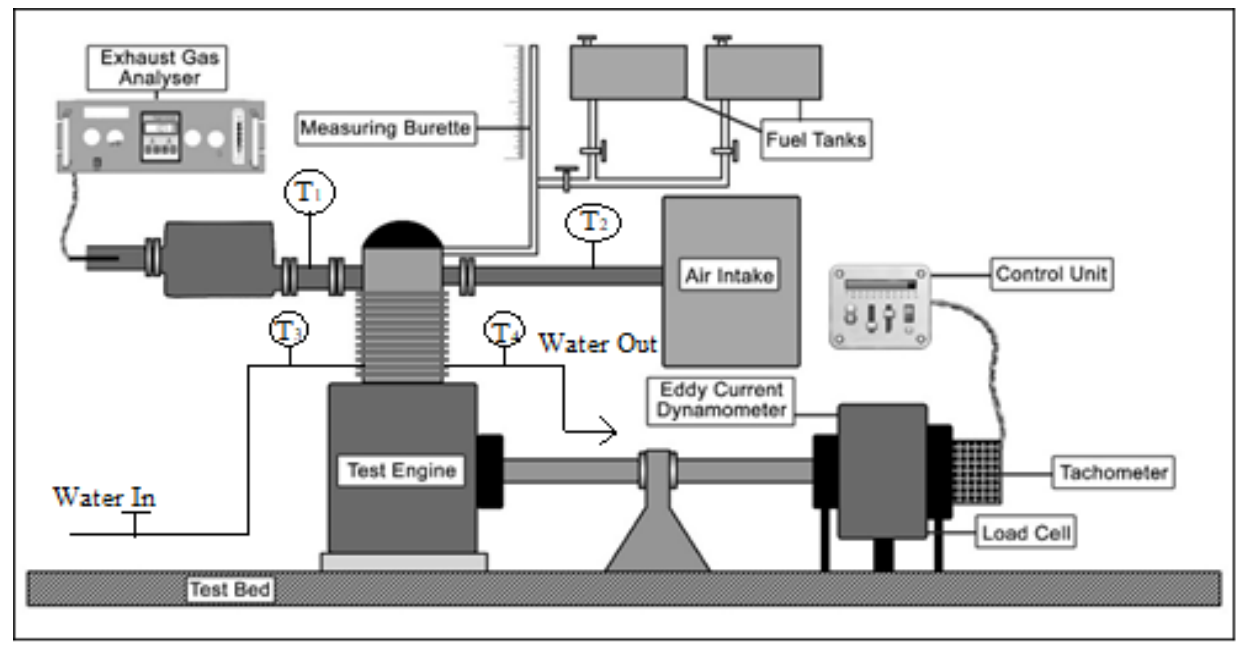

Figure 1. Experimental Engine setup

A computer was directly interfaced with the various measuring instruments via signals via a data acquisition system. The experimental engine technical specifications are set out in Table 1.

Table 1. Experimental engine details

\begin{tabular}{|c|c|}
\hline Make & Kirloskar \\
\hline General Details & $\begin{array}{c}\text { Four stroke, Compression } \\
\text { Ignition, Direct Injection }\end{array}$ \\
\hline Number of cylinders & One \\
\hline Cooling type & Water cooling \\
\hline Bore & $87.5 \mathrm{~mm}$ \\
\hline Stroke & $110 \mathrm{~mm}$ \\
\hline Cubic Capacity & $780^{\circ} \mathrm{cc}$ \\
\hline Compression ratio & $17.5: 1$ \\
\hline Swept volume & 737.8 \\
\hline Clearance volume & 42.2 \\
\hline Rated output & $5.81 \mathrm{~kW}$ at $1500 \mathrm{rpm}$ \\
\hline Duration of injection & $26^{\circ} \mathrm{BTDC}$ \\
\hline Inlet Valve Opens at & $4.5 \mathrm{BTDC}$ \\
\hline Inlet Valve Closes at & $35.5^{\circ} \mathrm{ABDC}$ \\
\hline Exhaust Valve Opens at & $35.5^{\circ} \mathrm{BBDC}$ \\
\hline Exhaust Valve Closes at & $4.5 \mathrm{~A}^{\circ} \mathrm{TDC}$ \\
\hline
\end{tabular}

\section{Results \& Discussion}

Brake Thermal Efficiency

The deviation of brake thermal efficiency (BTE) with respect to the brake power of all tested fuels is shown in Figure 2. From the graph, it shows the brake thermal efficiency raise with increases of

brake power of various load conditions with different fuel blends [16]. Because of reduced heat loss obtained at maximum loads that will lead to increasing the flow rate of the fuel and brake power of an engine. However, flow rate of fuel was increased with increasing the brake power higher load conditions and slightly thermal efficiency is decreased of all loads and that pure biodiesel (B100) shows lower BTE than other blends [17].But remaining biodiesel blends like B40, B60, B80, and pure biodiesel B100 shows lower than that of diesel fuel and B20 blend fuel also. Because of increasing the biodiesel blends percentage simultaneously there will bedecreasinginthe calorific value (CV) of fuel. It has observed that BTEis decreased in higher blend ratios. The calorific values of fuel lead to increasing the efficiency of an engine [18].

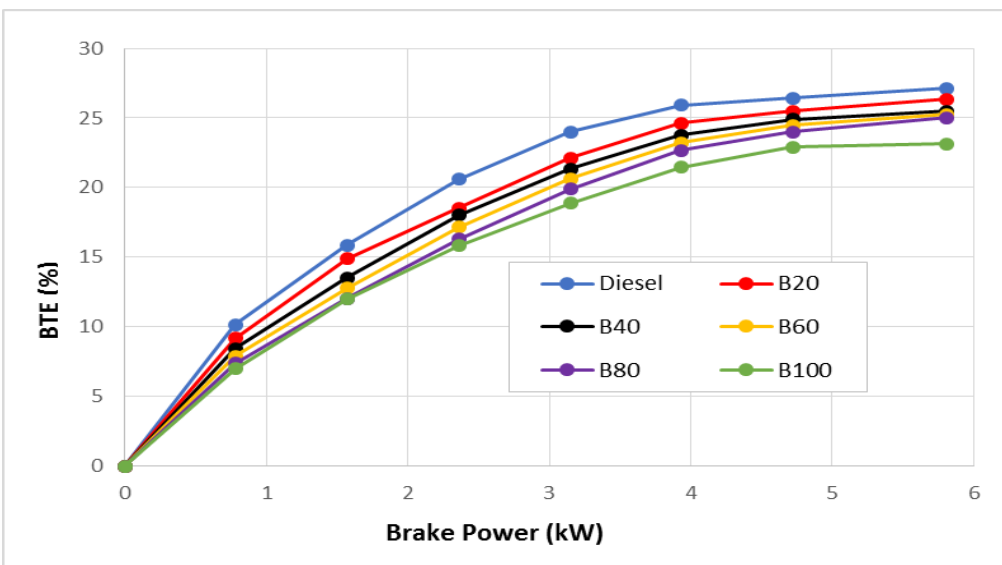

Figure 2.BTE for different blends 


\section{Brake Specific Energy Consumption}

Brake Specific Energy Consumption (BSEC) is equal to the product of Brake Specific Fuel Consumption (BSFC) and Calorific Value (CV) of the fuel.It is one of the engine parameters for measuring the engine fuel consumption by energy thusit means that how efficiently energy from fuel is obtained. Figure 3.shows the variation in the Brake Specific Energy Consumption (BSEC) at the engine speed of 1500 rpm with respect to brake power. In general, the BSEC values of biodiesel fuels for all brake powers are marginally higher than that of diesel and are increased with a rise in the percentage of blending
[19-20].The specific energy of the fuel depends on the properties of fuel including density, flash, fire point, calorific value, Cetane number and viscosity. For comparing the diesel with biodiesel, calorific value is less and having high viscosity and Cetane number in it. Hence it is led to increase the fuel consumption in biodiesel blends [21]. Specific energy depends on how much the heat energy is release from combustion in the engine cylinder.The BSECs of B20, B40, B60, B80 and B100 are $8.5 \%$, $19.2 \%, 24.1 \%, 26.3 \%$, and $29.6 \%$ higher than that of diesel withfull load conditions.

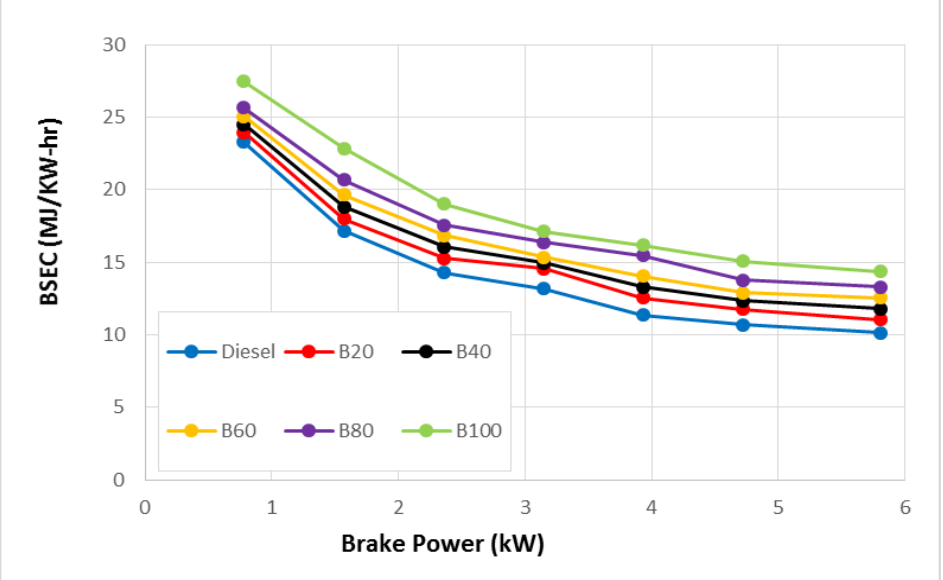

Figure 3. BSEC for different blends

\section{Exhaust Gas Temperature}

In theFigure 4.illustrates the Exhaust Gas Temperature (EGT) is varying with the brake power at the same time temperature of the exhaust gas is increases with the raiseof brake power.All the combinations of percentage of biodiesel blends have more EGT than diesel fuel. This is because of oxygen present in it, which develops the combustion process and leads to a higher exhaust gas temperature. The EGT of B20, B40, B60, B80 and B100 at a brake power of $5.81 \mathrm{~kW}$ (maximum load condition) is $6.5 \%, 10.3 \%, 14.8 \%, 15.8 \%$ and $17.6 \%$ higher than of a neat diesel fuel [22].

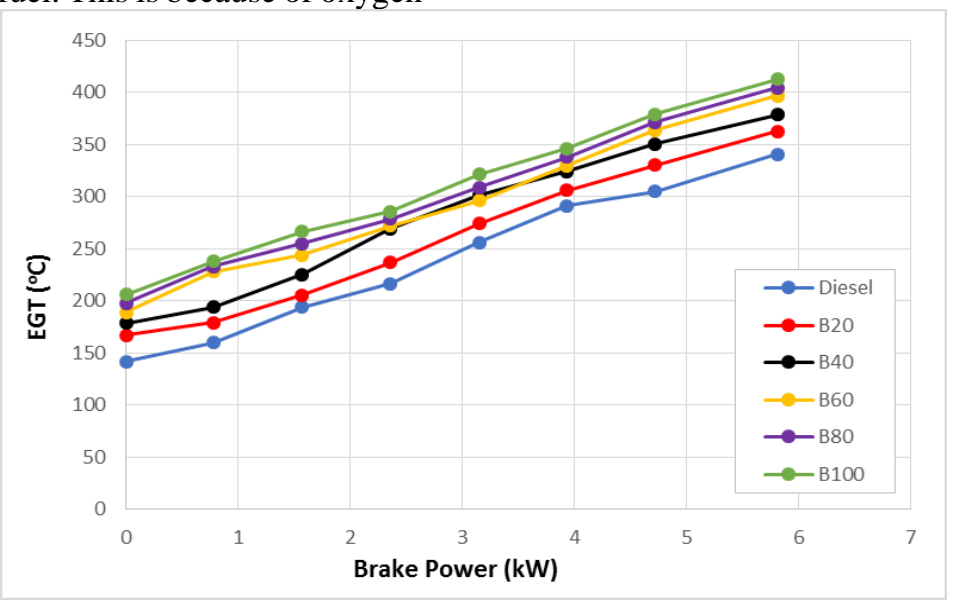

Figure 4. EGT for different blends

In-cylinder Pressure

The engine performance and exhaust emission can be analysed efficiently by means of In-cylinder pressure. The same data pressure may help to define the heat release rate of an engine cylinder during combustion process, which is based on the first law of thermodynamic. During the preliminary combustion stage (premixed burning phase), the maximum Incylinder pressure of a compression ignition engine depends upon on the fraction of fuel burnt in it. The obtained pressure in engine cylinder is having an ability to mix proper air-fuel. Figure 5.revealed the In-cylinder pressure for a different crank angle of engine specified for various biodiesel blends and 
diesel fuel. The figure shows the significant data at $1500 \mathrm{rpm}$ with the maximum load condition for simplicity. This illustrates that 69 bar at $10^{\circ} \mathrm{CA}$ ATDC was peak In-cylinder pressure obtained for diesel fuel. In addition to that diesel of 65.4 bar at $12^{\circ} \mathrm{CA}$ ATDC was the second highest pressure obtained in the B20 blend. Peak pressure of engine decreases while using a high percentage of blend ratios. This may be caused by the lesser range of biodiesel cetane number. Less the cetane number means a more the ignition delay, taking longer time to vaporize the fuel before it start of the combustion process [23].

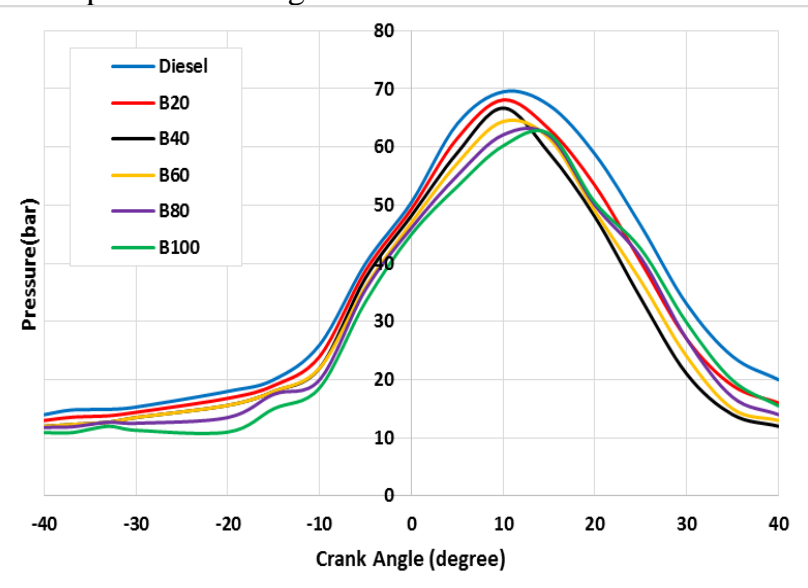

Figure 5.In-cylinder pressure for Different Blends

\section{Heat Release}

Figure 6.illustrates the deviation of the heat release (HR) of diesel and mahua oil biodiesel blend at maximum load relative to the crank angle. At the beginning of the combustion, a negative heat release (HR) was observed because of the delay in the vaporization of the fuel collected through the ignition delay. After the initiation of combustion began, this became positive. From this graph, it can be understood that the maximum heat release was $10^{\circ}$ CA BTDC for pure diesel and $12^{\circ} \mathrm{CA}$ BTDC for the B20 blend. It also shows that highest heat release obtained in the use of diesel (89Joule $/{ }^{\circ} \mathrm{CA}$ ). And second highest was B20 blend $\left(78 \mathrm{Joule} /{ }^{\circ} \mathrm{CA}\right)$ compared to remaining blends of biodiesel fuel. In comparison to biodiesel blends, diesel fuel has better mixing properties with air and also heat release with highest volatility during combustion process [24].

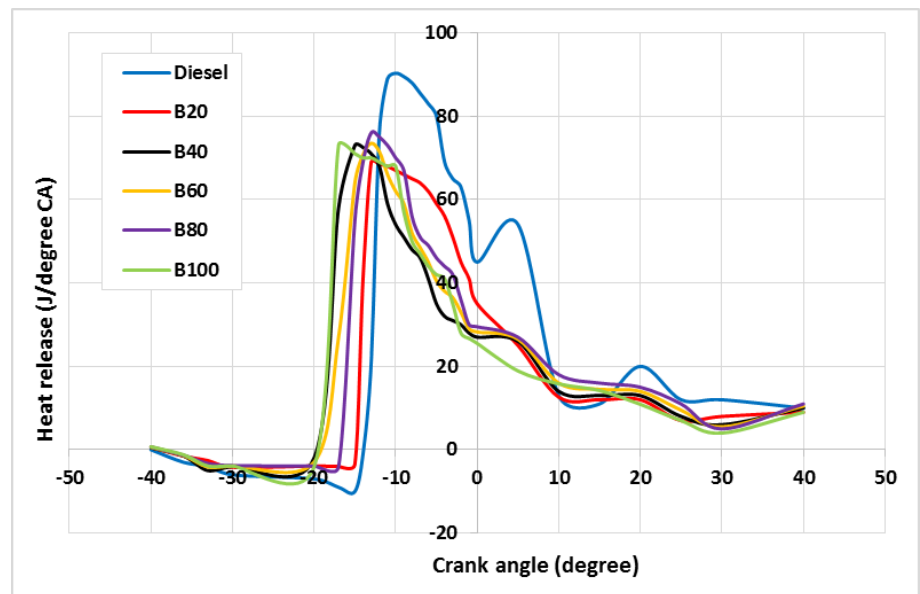

Figure 6. Heat Release for Different Blends Fuel

\section{Ignition Delay}

Actually in CI-engine combustion ignition delay was derived of two types. One is the physical delay and another one chemical delay [25]. The physical delay means the delay of mixing fuel and air during the combustion process due to a mechanical imbalance in the engine.The chemical delay means an occurrence in air/fuel mixture's pre-combustion effects.Engine ignition delay was reduced with increased brake power due to this the cylinder gas temperature of the engine is increased and reduced the physical delay. Engine ignition delay variation from the brake power for all experimental tested fuelsis revealed in Figure 7. As per the graphdue to the increasing blend ratio of a biodiesel, increased the ignition delay due to the biodiesel properties like Viscosity, density, cetane numberetc. As similar to found in full load condition (break power of $5.81 \mathrm{~kW}$ ), the B20 blend ignition delay is $2.1^{\circ} \mathrm{CA}$ longer than diesel fuel. Expect B20, 
Remaining blending ratio are high ignition delay [26-

28].

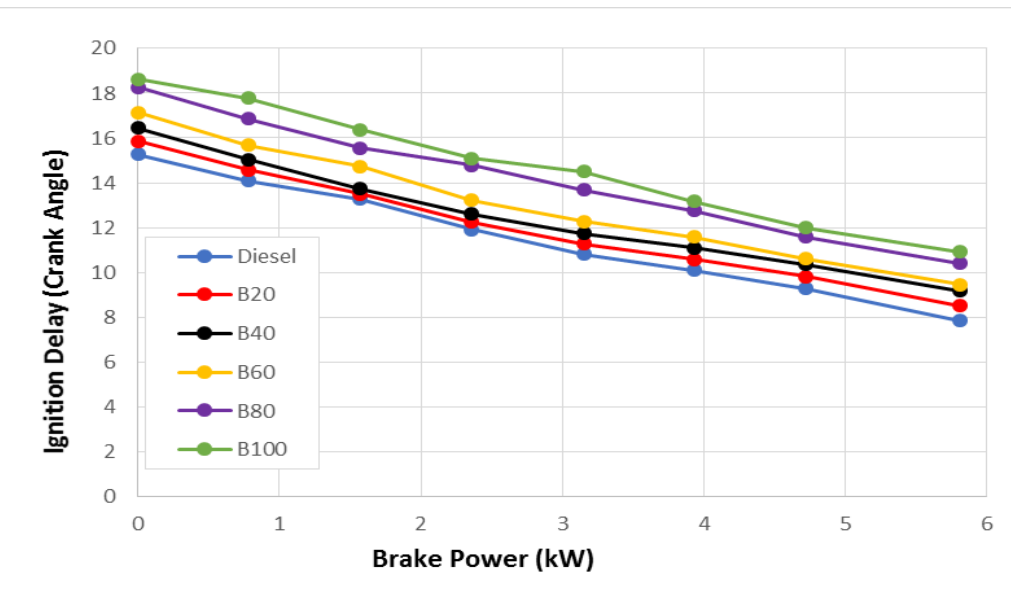

Figure 7. Ignition delay for different Biodiesel blends

\section{Unburned HydrocarbonEmission}

Hydrocarbons (HC) are the result of incomplete combustion of a fuel. Figure 8.gives the clear idea of the hydrocarbon emissions with brake power for differentblends of biofuel.For diesel fuel, the HC emission decreases with an increased in engine load as the combustion temperature is increased with a higher engine load [29]. For a blended biodiesel, HC emissions are lower than diesel emissions and decrease with an increase in the biodiesel fuel. The graph shows that the $\mathrm{HC}$ emissions for B20, B40, $\mathrm{B} 60, \mathrm{~B} 80$, and $\mathrm{B} 100$ are $15.4 \%, 26.7 \%, 28.72 \%$, $32.2 \%$ and $42.1 \%$ is lower respectively when compared with diesel fuel at full load brake power. Fuel must properly atomize thoroughly mixed and ignite for efficient combustion. Atomization and fuel mixing are again depend upon on the fuel's physical properties.

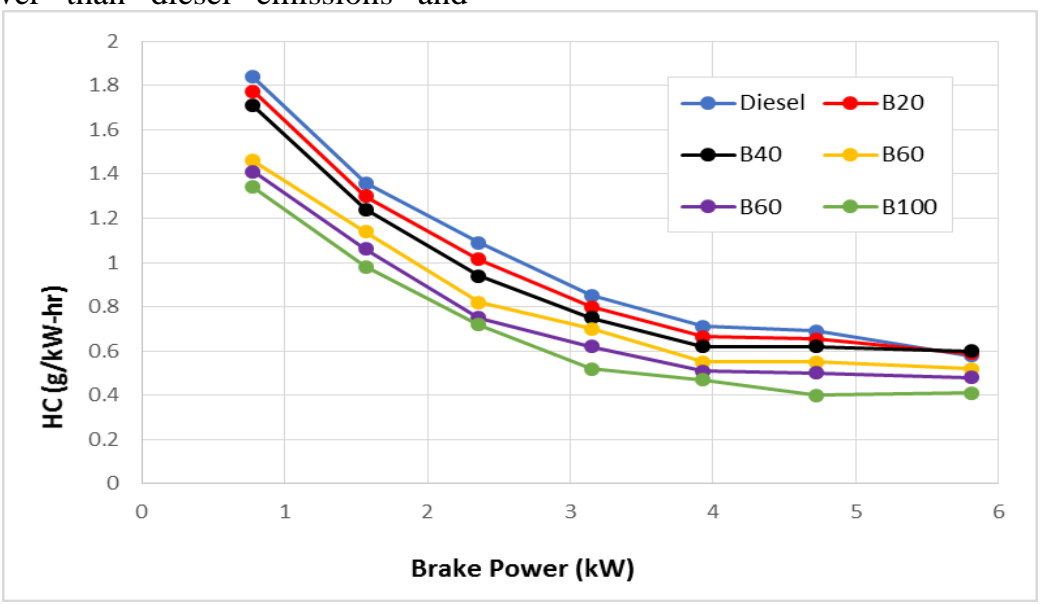

Figure 8. $\quad$ HC emission for Different Blends

\section{Carbon Monoxide Emission}

Figure 9.shows the variation in emissions of carbon monoxide (CO) from the brake power. At lower loads conditions, carbon monoxide emissions are higher than the maximum loads. This trend may be due to the presence of a rich combustible mixture with a maximum load. Like HC emissions, biodiesel emissions also have their mixtures lower than diesel fuel.CO emissions are maximum for pure diesel due to poor spray characterization, resulting the insufficient combustion, which increases the formation of $\mathrm{CO}$. B20, B40, B60, B80, and B100 produced $7.6 \%, 14.6 \%, 22.7 \%, 30.4 \%$, and $35.4 \%$ less $\mathrm{CO}$ emissions than diesel at full load. The presence of oxygen in the fuel, which in turn helps to support combustion processes and reduces the $\mathrm{CO}$ emissions from diesel fuel [30]. 


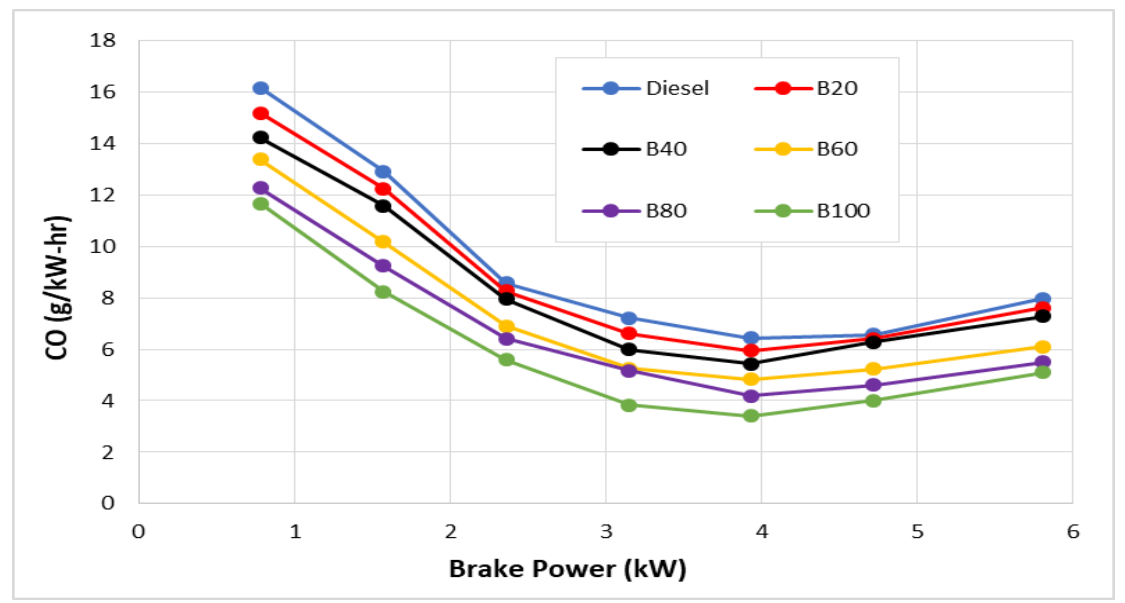

Figure 9. CO for Different Blends

\section{Oxides of Nitrogen Emission}

TheNitrous oxide (NOx) of nitrogen dioxide (NO2) and nitric oxide (NO) are in the exhaust gas emissions. The formation of NOx depends on the exhaust gas temperature, duration of the fuel reaction and the oxygen concentration in the fuel. Figure 10.gives the NOxformation decreases for the all tested fuels with increased brake power. At maximum load, however they decreased considerably. NOx emissions for B20, B40, B60, $\mathrm{B} 80$, and B100 were $14.4 \%, 17.8 \%, 21.6 \%, 28.5 \%$ and $32.9 \%$ higher compared to full load diesel. Increased biodiesel ignition delay promotes premixed combustion by allowing more fuel to be injected before ignition and can also be an alternative cause for increased NOx levels. And also the reason for increased NOx is low heat release [30].

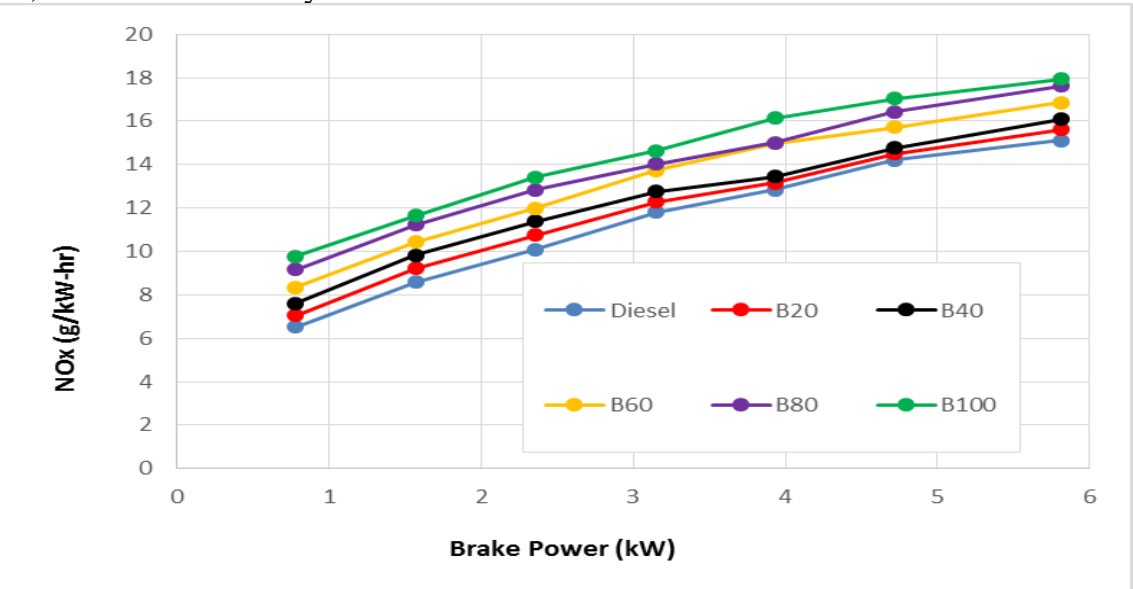

Figure $10 \quad \mathrm{NO}_{\mathrm{x}}$ for Different Blends

\section{Smoke Emissions}

Variations in thesmoke emissions from different blended fuels during the test are shown in Figure 11. The engine smoke is a function of the engine load, when there is an increasein the load of the engine, it leads to increase in the smoke density. In this connection, the smoke density rises from $5.6 \%$ to
$10.3 \%$ compared to diesel. The Figure 11 shows that the density of smoke value is increasing as the blending percentage of biodiesel increases, which is maximum than neat diesel. The maximum smoke density of neat biodiesel fuel is observed. The increase in smoke emissions results from the poor atomization of the biodiesel mixtures [29-30]. 


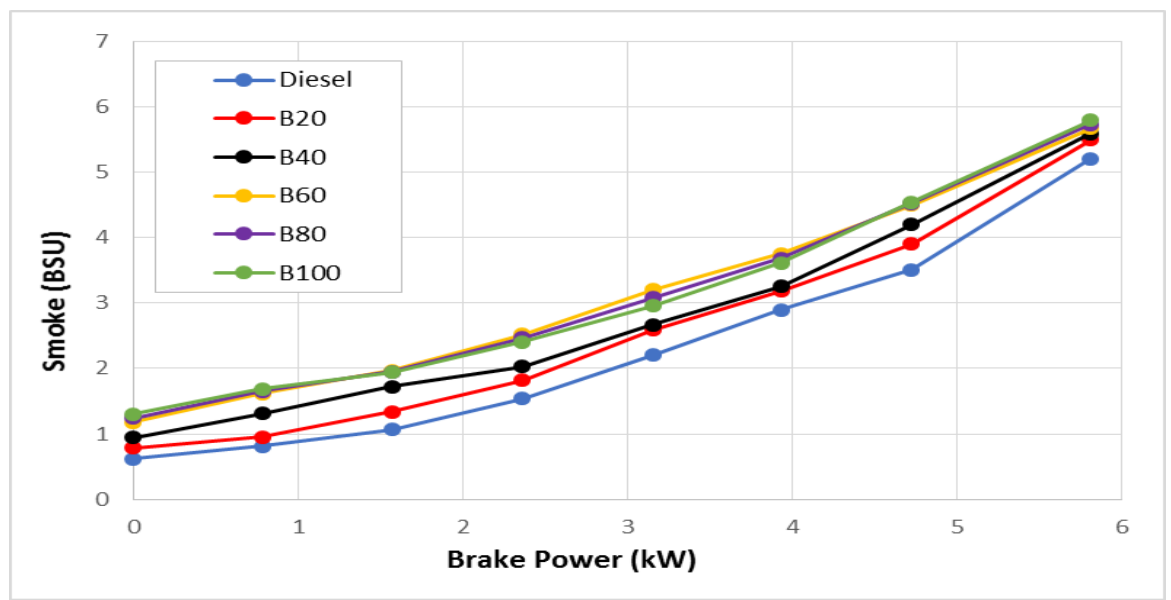

Figure 11. Smoke emission for Different Blends

\section{Conclusion}

A keen explore from experimental investigations are discussed in this analysis part. As per this the Conventional diesel engine runs with diesel fuel and mahua oil biodiesel blends (B20, B40, B60, B80 and $\mathrm{B} 100)$. The results are compared and analyzed through the performance, combustion and emission characteristics of engine. The best blend is B20 compared to other blends. Compared to diesel fuel, B20's BTE $2.59 \%$ less, BSEC is $8.9 \%$ more, EGT is $6.5 \%$ more, $\mathrm{HC}$ is $15.4 \%$ less, $\mathrm{CO}$ is $7.6 \%$ less, NOx is $14.4 \%$ high and smoke is between $5.6 \%$ to $10.3 \%$ more. The calorific value of B20 is better compared to other blends. This leads to enhance the thermal properties of the blend. B20 blend is decided as the optimal blend compared to diesel fuel.

\section{References:}

1. Kannan, M., Balaji, R., Babu, R.S., Bennita, M. and Kuppili, P., 2020. Computational analysis on combustion, characteristics and ignition analysis on IC engine using mahua oil. Materials Today: Proceedings.

2. Melvin Rajkumar R, Shafee S.M., Sathish S, Johnson Samuel, Balaji R, 2019., Experimental Analysis to Study the Tribological Behaviour Of Engine Oil with $\mathrm{ZnO}$ As Nano Additive. International Journal of Scientific \& Technology Research Volume 8, Issue 11

3. Sathiskumar, S., Suresh kumar, M., Kumar, R.V.R., Aswathaman, R. and Dhavaneeswaran, N., 2021, February. Effects of gasoline fumigation on the performance and emission characteristics of CI engine fuelled with mahua biodiesel. In AIP Conference Proceedings (Vol. 2317, No. 1, p. 030014). AIP Publishing LLC.

4. Jyothi, U.S., Santhi, S. and Jhansi, J., 2021. Performance enhancement approaches for Mahua biodiesel blend on diesel Engine. In Sustainable Manufacturing and
Design (pp. 201-222). Woodhead Publishing.

5. Pattanaik, B.P., Nayak, C. and Misra, R.D., 2021. Emission Studies on a Diesel Engine Fueled with Mixed Biodiesel Produced from Non-edible Oils. In Recent Advances in Mechanical Engineering (pp. 137-145). Springer, Singapore.

6. Nayak, S.K. and Pattanaik, B.P., 2014. Experimental investigation on performance and emission characteristics of a diesel engine fuelled with mahua biodiesel using additive. Energy procedia, 54, pp.569-579.

7. Lenin, A.H., Ravi, R. and Thyagarajan, K., 2013. Performance characteristics of a diesel engine using mahua biodiesel as alternate fuel. Iranica Journal of Energy \& Environment, 4(2), pp.136-141.

8. Godiganur, S., Murthy, C.S. and Reddy, R.P., 2009. 6BTA 5.9 G2-1 Cummins engine performance and emission tests using methyl ester mahua (Madhuca indica) oil/diesel blends. Renewable energy, 34(10), pp.2172-2177.

9. Devarajan, Y., Nagappan, B. and Subbiah, G., 2019. A comprehensive study on emission and performance characteristics of a diesel engine fueled with nanoparticleblended biodiesel. Environmental Science and Pollution Research, 26(11), pp.1066210672.

10. Rao, K.P. and Rao, B.A., 2017. Parametric optimization for performance and emissions of an IDI engine with Mahua biodiesel. Egyptian journal of petroleum, 26(3), pp.733-743.

11. Nayak, S.K. and Pattanaik, B.P., 2014. Experimental investigation on performance and emission characteristics of a diesel engine fuelled with mahua biodiesel using additive. Energy procedia, 54, pp.569-579. 
12. Rao, K.P. and Reddi, V., 2020. Parametric optimization for performance and emissions of DI diesel engine with Mahua biodiesel along with Diethyl ether as an additive. Biofuels, 11(1), pp.37-47.

13. Raju, V.D., Kumar, K.K. and Kishore, P.S., 2016. Engine performance and emission characteristics of a direct injection diesel engine fuelled with 1-hexanol as a fuel additive in mahua seed oil biodiesel blends. Int. J. of Thermal \& Environmental engineering, 13(2), pp.121-127.

14. Tandale, M.S., Garjepatil, G.V. and Jadhav, S.D., 2016. Optimization of performance and emission characteristics of compressed ignition engine operated on Mahua biodiesel using Taguchi and multiple regression analysis. In Proceedings of the World Congress on Engineering (Vol. 2).

15. Modi, M.A., Patel, T.M. and Rathod, G.P., 2014. Parametric Optimization Of Single Cylinder Diesel Engine By Taguchi Approach Using Palm Seed Biodiesel. Icciet 1, 5 .

16. Kumar, A.J.P., Sivakumar, S., Balaji, R. and Nadarajan, M., A Novel Banana Leaf Waste-Based Activated Carbon for Automobile Emission Control. Trends in Manufacturing and Engineering Management, pp.977-989.

17. Kumar, J.P., Sivakumar, S., Balaji, R., Sathish, S. and Nadarajan, M., 2020. Effective Utilization of Banana Plant Waste Materials for Catalytic Converter Filter in Kirloskar Diesel Engine. Materials Today: Proceedings, 24, pp.2174-2184.

18. Soudagar, M.E.M., Banapurmath, N.R., Afzal, A., Hossain, N., Abbas, M.M., Haniffa, M.A.C.M., Naik, B., Ahmed, W., Nizamuddin, S. and Mubarak, N.M., 2020. Study of diesel engine characteristics by adding nanosized zinc oxide and diethyl ether additives in Mahua biodiesel-diesel fuel blend. Scientific reports, 10(1), pp.117.

19. Dugala, N.S., Goindi, G.S. and Sharma, A., 2020. Evaluation of physicochemical characteristics of Mahua (Madhuca indica) and Jatropha (Jatropha curcas) dual biodiesel blends with diesel. Journal of King Saud University-Engineering Sciences.

20. Rao, K.P. and Reddi, V., 2020. Parametric optimization for performance and emissions of DI diesel engine with Mahua biodiesel along with Diethyl ether as an additive. Biofuels, 11(1), pp.37-47.

21. Gangula, V.R., Gopal, G.R.N. and Tarigonda, H., 2020. Investigation on Different Thermal Barrier-Coated Piston
Engines Using Mahua Biodiesel. Journal of The Institution of Engineers (India): Series $C$, pp.1-14.

22. Jyothi, U.S., Santhi, S. and Jhansi, J., 2021. Performance enhancement approaches for Mahua biodiesel blend on diesel Engine. In Sustainable Manufacturing and Design (pp. 201-222). Woodhead Publishing.

23. Bhale, P.V., Deshpande, N.V. and Thombre, S.B., 2009. Improving the low temperature properties of biodiesel fuel. Renewable energy, 34(3), pp.794-800.

24. Kumar, M.V., Babu, A.V. and Kumar, P.R., 2018. Experimental investigation on the effects of diesel and mahua biodiesel blended fuel in direct injection diesel engine modified by nozzle orifice diameters. Renewable energy, 119, pp.388399.

25. Raheman, H. and Ghadge, S.V., 2007. Performance of compression ignition engine with mahua (Madhuca indica) biodiesel. Fuel, 86(16), pp.2568-2573.

26. Puhan, S., Vedaraman, N., Ram, B.V., Sankarnarayanan, G. and Jeychandran, K., 2005. Mahua oil (Madhuca Indica seed oil) methyl ester as biodiesel-preparation and emission characterstics. Biomass and bioenergy, 28(1), pp.87-93.

27. Kumar, M.V., Babu, A.V., Kumar, P.R. and Reddy, S.S., 2018. Experimental investigation of the combustion characteristics of Mahua oil biodiesel-diesel blend using a DI diesel engine modified with EGR and nozzle hole orifice diameter. Biofuel Research Journal,5(3), p.863.

28. Puhan, S., Vedaraman, N., Sankaranarayanan, G. and Ram, B.V.B., 2005. Performance and emission study of Mahua oil (madhuca indica oil) ethyl ester in a 4-stroke natural aspirated direct injection diesel engine. Renewable energy, 30(8), pp.1269-1278.

29. Muthukumaran, C., Praniesh, R., Navamani, P., Swathi, R., Sharmila, G. and Kumar, N.M., 2017. Process optimization and kinetic modeling of biodiesel production using non-edible Madhuca indica oil. Fuel, 195, pp.217-225.

30. Devarajan, Y., Nagappan, B. and Subbiah, G., 2019. A comprehensive study on emission and performance characteristics of a diesel engine fueled with nanoparticleblended biodiesel. Environmental Science and Pollution Research, 26(11), pp.1066210672. 